Institutions, Unionisation and Voice: The Relative Impact of Context and Actors on Firm Level Practice.

Chris Brewster ${ }^{1}$ (Henley Business School, University of Reading), Geoffrey Wood (Warwick Business School) and Marc Goergen (Cardiff Business School)

1 (corresponding author), Chris Brewster, Henley Business School, University of Reading, Whiteknights, Reading, RG6 6AA, UK, c.j.brewster@henley.reading.ac.uk 


\title{
Institutions, Unionisation and Voice: The Relative Impact of Context and Actors on Firm Level Practice
}

\begin{abstract}
Trade unions provide a voice in the way firms are run, an input into reward systems and increased security of employment. But these vary with national context. Using transnational survey evidence, we explore the relative impact of setting, and of unions and collective bargaining, on these issues. We find that, irrespective of context organisations are significantly more likely to make usage of compulsory redundancies in the absence of unions and collective bargaining. However, in other areas, the impact of unions appeared less pronounced than that of the wider context. We explore the reasons behind this, and the broader policy implications thereof.
\end{abstract}

Key words: context, varieties of capitalism, trade unions, collective bargaining, nonunionism, reward systems, redundancies

Acknowledgements: We thank the members of the Cranet network who collected the data, Cranfield School of Management who co-ordinate the network, and the helpful comments and insights of the anonymous referees. 


\section{Institutions, unionisation and voice: The relative impact of context}

\section{and actors on firm level practice}

A key question in industrial relations concerns the comparative effect of unionisation and setting on employee voice. There is a long tradition in industrial relations research linking the presence or absence of trade unions and collective bargaining with elements of voice (see, for example, Haynes, Boxall and Macky, 2005; Gollan, 2000) and with security of tenure (Gall, 2003b). Kelly (1998: 4) argues that, whilst workers' rights under the law are important, and vary from context to context, mobilisation capabilities (the ability to attract members, to obtain collective representation and to bargain collectively) are also relevant. Much of the literature on industrial relations has focused on the consequences of variations in the capabilities of individual unions, and the relative utility of specific strategic choices (Kelly, 1998; Gall, 2003a). This would suggest, first, that there is much diversity within specific national settings and, second, that there is likely to be a close relationship between the presence or absence of a union within an individual firm, and the other features of the latter's work and employment relations (see Dundon and Rollinson, 2004: 5-6). Much of the literature on HRM too has focused on the distinctions between, on the one hand, those firms that retain traditional pluralistic employment relations paradigms encompassing union recognition and, on the other, those that have moved towards neo-unitarist policies or simply retained traditional unitarism (Dundon and Rollinson, 2004; Guest, 1987). This would suggest that, even if there are general tendencies towards the deregulation of labour markets, and more broadly speaking, the adoption of liberal market reforms, the strategic choices within individual firms remain important (Guest, 1987; c.f. Taras, 2006). 
By contrast, the contemporary institutional literature argues that the state of collective organisation at individual workplaces matters less than wider systemic features in the national economic system (Hall and Soskice, 2001: 30). Whilst this literature suggests that unions are likely to be stronger in some settings than others, this reflects the product of structural features and, hence, it accords rather less attention to differences in workplace level organisation and capabilities for collective mobilisation and action. In practical terms, the central issue is whether the relative position of workers within individual firms is primarily a product of setting, or is contingent on organisational capabilities at individual workplaces.

From within the broad institutional tradition, a number of accounts have linked embedded contextual features to specific areas of practice (Dore, 2000; Hall and Gingrich, 2004; Hall and Soskice, 2001; Lane and Wood, 2009). Much of this literature is based on fairly generalized assumptions as to what a representative firm in a particular setting does. However, to date, a limitation of much of the existing literature has been that predictions as to the relationship between institutions and practice have been founded on stylized ideal types, broad analyses of macro-economic trends, and/or limited numbers of case studies, rather than on systematic survey evidence as to actual firm level practice (see Dore, 2008). This paper seeks to deepen the empirical base of existing comparative frameworks, and to provide more nuanced insights into the nature of internal diversity within national institutional settings. We take as our touchstone the recognition or not of trade unions for collective bargaining and the presence or not of works councils or consultative committees. So our key research questions are: does the setting make a difference to employee voice 
and the downstream HRM practices? Is that difference irrespective of union mobilisation does unionisation, as opposed to non-unionism, impact employee voice and security of tenure? Does it make a lot of difference whether a union is recognised or not and, particularly, does it matter more in some settings rather than others?

\section{Differing Conceptualisations of Institutional Mediation}

There has been an increasing interest in the effects of institutional configurations on what firms do in different settings. Yet conceptualisations as to how institutions work vary greatly. A key distinction is between those approaches rooted in rational choice economics that see institutions as providers of incentives and the socio-economic approaches that see them as centres of webs of relations (Lane and Wood, 2009). The former focus on a single institutional feature that over-rides all others (Boyer, 2006), more specifically the institutional foundations of property rights, as providing incentives for rational actors (Botero Djankov, La Porta and Lopez-de-Silanes, 2004; Goergen, Brewster and Wood, 2009).

In practice, it is held that systems where property rights are the strongest are likely to provide the optimal incentives for investors (North, 1990). As strong investor rights are necessary to ensure capital markets are developed, it follows that anything that has the potential to detract from them is ultimately undesirable. This literature argues that owner and worker rights represent a zero-sum game; should one be stronger, then the other must necessarily be weaker (Botero et al., 2004; Goergen et al., 2009). However, when owners are more able to enforce their rights, firms will perform better, with trickle down benefits to all, even if at the costs of representation and accountability. In high property rights contexts, countervailing worker power will be weaker. 
Conversely, in situations where the rights of shareholders are most diluted, and stakeholder power relatively strong, formal structures for worker representation are most likely to be advanced (Dore 2000). Mixed systems are likely to face pressures to move towards one or other framework, ultimately more likely to be the high property rights option on account of its greater efficiencies (see Botero et al., 2004; North, 1990) ${ }^{i[i]}$. Such approaches deny the possibility of complementarity, whereby institutional arrangements make compromises possible that are beneficial to employers and workers alike. In contrast, heterodox or socioeconomic approaches to institutions see them as centres of networks of relationships. These networks serve as socialising agencies and condition the strategic interactions of various agents, in addition to conferring power on particular actors and, indeed, performing the above-mentioned role of providing incentives and disincentives to rational actors (Hall and Soskice 2001: 5). Embedded property rights are not necessarily more important than any set of social relations. Much of the literature on comparative capitalisms draws a central distinction between liberal market economies (LMEs) where shareholder rights are most advanced and co-ordinated market economies (CMEs) where they are less so (Hall and Soskice, 2001; Dore, 2000). In these approaches there is no inherent reason why one system should necessarily perform better than the other (Hall and Soskice, 2001; Hall and Gingrich, 2004). Implicit in this work is a defence of social democratic and other forms of non-liberal market capitalism.

In CMEs, it is held that relatively advanced forms of employee representation in the workplace may dilute owner/shareholder power, but that this is more than offset by greater employee commitment to the firm (Hall and Soskice 2001; Dore 2000). Stronger employee 
voice not only means that employee concerns and grievances are taken more seriously, but also that the knowledge employees hold on the process of production is more effectively harnessed (Gollan, 2009). Institutional arrangements within CMEs help maintain high levels of industry relevant skills that are beneficial both economically and socially (see Culpepper, 2001; Goergen, Brewster, Wood and Wilkinson, 2012). And, whilst owners may face a dilution of power at the point of production, this is offset by specific opportunities to advance their interests outside of the workplace (Morin, 2005): inter alia, through more effective employers associations, through neo-corporatist deal making and through more long term relationships with customers and suppliers.

In LMEs, there is a far greater emphasis on adversarial competition, weaker employee rights, short term contracting and more fluid labour markets (Hall and Soskice, 2001). However, even in such contexts, labour skills formation matters a great deal. Relatively large numbers of highly mobile graduates with generic skills are conducive to high technology industries, whilst in more traditional manufacturing industries persistent collective arrangements at firm level may continue to promote human capital development (Estevez-Abe et al., 2001: 163).

There have been numerous developments, extensions and critiques of the Hall and Soskice (2001) approach (c.f. Hancke et al., 2007; Lane and Wood, 2009). Firstly, underlying the dichotomous approach was the assumption that only the LME and CME models had known complementarities and that other models would inevitably converge with one or the other (Hall and Soskice, 2001: 18-19). Since then there has been growing recognition not only that other types of capitalism may continue to develop on distinct lines but without the 
developed complementarities associated with the mature capitalist archetypes (Hancke, 2007). This would include the linkages between the formal regulation of labour markets and the nature of employee representation within the workplace. In less developed archetypes, such as mixed market economies (MMEs, the Mediterranean world) and emerging market economies (EMEs, the ex-communist states of central and eastern Europe), not only are different aspects of legislation and practice not nearly so closely aligned, but also enforcement of labour law is much weaker (Hancke et al., 2007; Psychogios and Wood, 2010). In short, one is less likely to encounter a close association between wider social context, and between one form of employee representation (such as collective bargaining) and another.

Secondly, the approach assumes that institutional features are closely enmeshed, together creating complementarities in a manner that would not be possible if they were encountered alone (Hall and Soskice, 2001: 18). Hence, it would be unlikely that any specific firm level practice would be the sole product of a single institutional feature. Subsequent chapters in the Hall and Soskice volume are by no means so confident in terms of country categorisations, the durability of specific national models, and the relative closeness of institutional coupling. For example, Hancke (2001: 307) argues that the old French system has been depleted, and has been replaced by a new model that is more under the sway of Anglo-Saxon influences. Culpepper (2001: 275) argues that even when countries lack the overall institutional framework encountered in CMEs, there is room for policy initiatives that create coordination in specific policy areas. In practice, parties may cooperate on a decentralized level on regional and/or sectoral lines ( Culpepper, 2001: 288). 
Although they differ on the relative desirability of worker rights, both the legal origin and varieties of capitalism approaches suggest that employee voice will be stronger in CMEs/stakeholder orientated systems; even if a union is not present, there are likely to be other mechanisms, such as legally mandated works councils or voluntary joint consultative committees, through which employees mediate owner power. Hence, the literature on comparative capitalisms (Deeg and Jackson, 2008) and, indeed, the rational-hierarchical accounts associated with the economics and finance literature, implicitly or explicitly suggest that shareholder dominant liberal market economies (LMEs) are associated not only with weaker collective voice, but also a reduced emphasis on employee input into key issues such as employment security. In other words, the argument is that the nature and extent of voice are systemically driven, through both embedded formal rules or conventions and informal ones. In practice, there are of course many firms in LMEs that adopt broadly cooperative practices and many within CMEs that are unitarist. This raises a question as to whether firms departing from the norm are challenging the system through pioneering new sets of practices, are a historical residue from a previous institutional order, or are broadly adhering to a specific model even if they depart from certain systemic features (Dore, 2008).

\section{Regulation of the Employment Contract}

The employment contract is an uncertain exchange between employers and workers: a readily quantifiable wage is exchanged for an uncertain amount of labour power (Hyman, 1975). From an employer point of view, key concerns include maximizing the quantity or quality of output for the wage accorded (Deckop et al., 1999). From a worker point of view, a key concern is the relative ability to impart predictability into the employment relationship, regulating the exercise of managerial power (Bryson et al., 2006; Kelly, 1998). 
There is a very broad body of literature on the role of trade unions that suggests that one of their primary functions is rule making, formalizing the boundaries of managerial authority, and institutionalizing the process of bargaining between employers and employees (Marsden, 1999: 110-111). Employee voice is central to this function but the form of voice matters. Collective bargaining is one possible forum and so are works councils or joint consultative committees. These represent, in many different settings, an important forum for negotiating changes to the social organisation of work. Indeed, it can be argued that, as they are collective and representative bodies, they are intrinsically a more effective mechanism for representing worker concerns than individual or direct forms of worker involvement (Dundon, 2002) which may not only be little more than "a broken telephone", but may serve to hamper future organisational initiatives (Kaufman and Taras, 2000: 10-11; Terry, 1999; see also Gollan, 2005, 2006). Indeed, voice may even be used as a means of capturing workers' insider knowledge so that they can be more readily dispensed with (Terry, 1999). Where unions are not recognised for collective bargaining, it could be argued that the 'pull' of national institutions may be weaker, enforcement of the letter and spirit of the law less effective and national level social compromises more likely to be contested (see Boyer, 2010).

Within firms where the unions are not recognised, Kaufman (2004) argues that managers will seek to confine employee voice narrowly for fear that it will develop towards collective voice; in unionised firms, this has already occurred. In many CMEs, employers of a certain size are obliged to have works councils, and pan-European firms of a certain size, European Works Councils. The latter vary in their relative strength from context to context, ranging from German-type works councils where co-determinative rights are entrenched by law, to 
relatively weak European Works Councils that, at the bare minimum, may be primarily consultative bodies (Ramsay, 2003). Nonetheless, research reveals that firms which had works councils in place - regardless of whether they were weak or strong - appeared to be more likely to recognise unions than those where these were absent (Brewster et al., 2007b). In other words, works councils and joint consultative committees (JCCS) appear to have a general impact on employment relations policies that appears to transcend their formal role under the law. Hence, it could be argued that the presence or absence of a JCC or works council represents an important indicator of the countervailing power of workers (Rogers and Streeck, 1995).

A key concern is employment security. It has been noted that "jobs are always at the mercy of economic and technological vagaries" (Hyman, 2002: 57). This would suggest that a key feature of relative worker power - whether representing a product of systemic features or workplace level organisational capabilities - is the extent to which workers are able to constrain the usage of redundancies and outsourcing. Whilst technological or external economic shocks may cost jobs, there are a range of softer mechanisms firms have at their disposal, such as redeployments, early retirement policies, or hiring freezes (see Wilkinson, 2005). Unionisation or non-unionisation may impact upon managers choices.

\section{Employee Representation in Non-Union Firms: Existing Research}

Budd, Gollan and Wilkinson (2009: 2) note that voice may either be collective and representative or individual and direct. The former includes forms such as collective bargaining, works councils and joint consultative committees. The latter encompasses informal interactions between employer and employees, and more formal structures for 
involvement, such as managerial briefings, suggestion schemes or quality circles (Brewster, Wood, Croucher and Brookes 2007a; Budd et al., 2009: 2). In non-union and weak union environments informal interchanges may assume a particular importance. However, what sets formal non-union voice mechanisms apart is that they only involve employees within the enterprise, with little or no external involvement or resources from unions, whilst they operate on company resources (Gollan, 2009: 213; Taras and Kaufman, 2006). Whilst recognizing the importance of informal interactions, this article concentrates on involvement and participation through formalised processes and procedures.

Where unions are strongest, and where they have gained recognition for collective bargaining, evidence of their countervailing power on firm practices will be most pronounced (Cooke, 1994; Bryson et al., 2006). In turn, it can be argued that this would make for much diversity within national settings, in line with sectoral and regional variations in union traditions, and the real strategic choices made by leaderships (Gall, 2003a). Indeed, Bechter Brandl and Meardi, (2012) found that there was as much variation in industrial relations practice within European countries as between them. Hence, we explore sectoral differences.

\section{Key Issues}

From this account it follows that we are primarily interested in three issues. The first of these concerns setting and its impact on employee voice mechanisms and whether unions have collective bargaining rights at the workplace either by law (in some national contexts mostly CMEs - works councils are compulsory under the law) and/or through collective strength. It has been argued that there is a clear relationship between unionisation and 
collective bargaining on the one hand and the presence or absence of a works council or JCC on the other hand. Gollan (2009: 212) argues that non-union collective voice "has tended to play a minimal role in many Anglo industrial relations systems, with few formal processes or legal requirements". Brewster et al. (2007a) found that the presence of a union is correlated with the existence of works councils and JCCs. Are these collective forms of representation likely to coincide with the presence or absence of a union, and/or are these primarily a product of setting?

Implicit in all institutional accounts is an assumption that setting is likely to mould practice. This may involve either a division of mature capitalisms into LMEs and CMEs (with possible other archetypes encompassing less developed emerging or mixed economies) or the allocation of countries to a scale according to the relative strength of owner and countervailing employee rights (see also Bosch, Rubery and Lehndorff, 2007):

Hypothesis 1a: firms in CMEs are more likely to have collective representational voice than firms in other capitalist archetypes

Hypothesis 1b: firms from settings with stronger shareholder rights are less likely to have collective representational rights than firms from countries with weaker shareholder rights

The first hypothesis may seem an obvious one, and one that is easily provable, but it provides a foundation for subsequent hypotheses. The subsequent hypotheses centre on the extent to which trade unions impact on key issues for workers within the firm. 
Further, there is the issue of security of tenure and the relative willingness to deploy "harder" forms of adjusting workforce sizes, such as redundancies and outsourcing (Wilkinson, 2005). Trade unions aim, perhaps above all, to protect the security of their members (see Gall, 2003a, 2003b). Security has many components but a significant one is the individual's ability to resist being made redundant against their will - compulsory redundancy. It seems likely that unions will strive to avoid compulsory redundancies or redeployments wherever possible (Gall, 2003b: 87). They might also be expected to oppose outsourcing of work and jobs. In both cases, where the management of the firm is able to convince the unions that labour costs need to be cut drastically, they will generally prefer "softer" options such as voluntary redundancy.

Hypothesis 2a: where collective representation is strongest, the use of compulsory redundancies will be lower, irrespective of setting

Hypothesis $2 \mathrm{~b}$ : where collective representation is strongest, the use of outsourcing will be lower, irrespective of setting

\section{Method}

This data analysis is based on the Cranet survey, 2004/05. This wave covers a total of 32 countries from Western Europe, North America, Eastern Europe as well as transitional economies (see Table 1 for the list of countries). The survey covers all sectors within the countries surveyed, only excluding smaller firms (those with less than 100 employees), and probes HRM policies and practices in private and public organisation. However, in this study we focus on theformer. The survey primarily concentrates on factual information, rather 
than subjective opinions and, hence, uses mostly closed-ended questions. Full details on survey methodology are provided by Brewster, Mayrhofer and Morley (2004). Given their importance in explaining differences in industrial relations (Doellgast, Holtgrewe and Deery, 2009; Ferrer and Lluis, 2009), we checked not just for country and variety of capitalism but also for differences related to size and sector. In what follows, non-union firms are defined as those that do not recognise a union for collective bargaining.

We acknowledge that the exclusion of small firms constitutes a limitation of this research, especially given that they are generally exempt from compulsory works council legislation in force in many CMEs. The work and employment relations policies in smaller firms in CMEs that lack the restraining presence of a works council are likely to be very different (c.f. Lane and Wood, 2009). Furthermore, union presence is largely a function of firm size: the vast majority of small firms have no union representation. What we do here is to compare unionised and non-unionised medium-sized and larger firms so that we are, as far as possible, comparing like with like.

\section{<<Table 1 about here»>}

Recognising unions for collective bargaining refers to responses to the survey question asking firms if they "recognize a union" (at organisational level) for the purpose of collective bargaining. This is not necessarily the same thing as being engaged in collective bargaining at national/regional/firm levels. It is possible that a firm may be bound by national or regional collective bargaining agreements (and, indeed, in rare cases be represented at the collective bargaining table via the relevant employer association), yet have a union presence 
in their own organisation that falls below de factor or de jure criteria for recognition. We acknowledge that a scrutiny of variations in industry and national collective bargaining coverage might yield somewhat different results that might be even more closely bound up with national institutional setting.

On average, and unsurprisingly given the European focus and the exclusion of very small organisations, only $28 \%$ of the sample firms fall into the non-union category.

\section{Findings}

Given that we look at the absence or presence of both union recognition and non-union voice, i.e. the presence of a works council or JCC, we have four different categories of firms (see Table 2).

Firms that both recognise unions for collective bargaining and have a works council (or JCC) are the most frequent, constituting roughly $44 \%$ of the sample. Firms with neither are the second most common occurrence, and amount to $20 \%$ of the sample, followed by firms that recognise a trade union, but do not have a works council ( $17 \%$ of the firms). Finally, less than $8 \%$ of firms surveyed did not recognise a trade union, but still had a works council or JCC in place; in other words, there was a strong linkage between union recognition and the presence of a works council or JCC.

<<Table 2 about here»> 


\section{Setting, Works Councils/JCCs and Collective Bargaining}

Table 3 and Table 4 test the validity of Hypothesis $1 \mathrm{a}$ and Hypothesis $1 \mathrm{~b}$, respectively. Table 3 distinguishes between firms from CMEs, LMEs, EMEs, MMEs and other countries. The LMEs in our sample are Australia, Canada, New Zealand, the UK and the USA. CMEs covered here are Austria, Belgium, Denmark, Finland, France, Germany, Iceland, the Netherlands, Norway, Slovenia, Sweden and Switzerland. EMEs include Bulgaria, the Czech Republic, Estonia, Hungary and Slovakia. MMEs cover Cyprus, Greece, Israel, Italy and Spain. All remaining countries fall under the "other" category; emerging markets where institutional arrangements are even more fluid and uneven in coverage. Israel is different from other MMEs in terms of issues such as the relative role of the security sector, the role of the state in agricultural policy, and immigration policy. Hence, we checked whether the link between capitalism and non-union voice was affected by this different categorisation of Israel. ${ }^{\text {ii[i] }}$

Each column of Panel A of Table 3 reports the percentage of firms from each of the five varieties of capitalism for each of the four categories of firms. The table shows that firms from LMEs are more likely to have neither collective bargaining nor works councils; the latter may be partially a function of the law, given that in some CMEs it is compulsory for firms above a specific size to have a works council. What is apparent is that CMEs in this respect are very different to less mature capitalist archetypes. Indeed, both union and formal non-union voice - independent of the existence of collective bargaining - are strongest in firms from CMEs, again, a feature distinct from all the other archetypes. This supports Hypothesis 1a. Panel B of Table 3 reports that there are statistically significant differences in these percentages. In detail, firms from CMEs are more heavily present among the category of firms with both collective bargaining and works councils compared 
to all other varieties of capitalism. Irrespective of whether firms were unionised or not, works councils/JCCs were less common in liberal market economies: it appears the latter are less an expression of union power, or managerial attempts at union substitution, than simply of context (see Rogers and Streeck, 1995).

As mentioned above, a case can be made for categorising Israel among the 'other' variety of capitalism rather than as an MME, with some similarities to the Mediterranean world. In this case, the percentages in Panel A of Table 3 do not change qualitatively. However, there are some changes in Panel B with respect to the differences in percentages. These differences all relate to the MME column. In detail, there is no longer a significant difference between MMEs and the 'other' variety of capitalism with respect to the percentage of organisations with no collective bargaining, but a works council. There is also no longer a significant difference between MMEs and LMEs with respect to the percentage of organisations with collective bargaining, but no works council. Finally, there is now a significant difference between the MMEs and the 'other' variety in terms of the percentage of firms with both collective bargaining and non-union voice.

<<Table 3 about here»>

Table 4 is based on the Djankov et al. (2008) anti-self-dealing index. The index measures the level of protection enjoyed by minority shareholders. According to Djankov et al., this index has a stronger theoretical basis than the La Porta et al. (1997b, 1998) anti-directors-rights index which was constructed in a fairly 'ad hoc' way. The anti-self-dealing index looks at transactions of corporate self-dealing, i.e. self-dealing by the controlling shareholder, and 
then counts the number of hurdles that the controlling shareholder will have to jump to engage in these transactions. Panel A of Table 4 suggests that there is an inverse relationship between investor rights as measured by the anti-self-dealing index and the union and non-union voice of employees. Firms with both collective bargaining and a works council are on average from countries with weaker investor rights whereas firms with neither are from countries with the strongest investor rights, as predicted by Botero et al. (2004). Panel B suggests that these differences in the investor protection index are not just of economic significance, but also of statistical significance. This supports Hypothesis $1 \mathrm{~b}$. There is no significant difference between firms without any voice (whether union or nonunion) and those with a works council/JCC only, perhaps indicating that without union backing works councils/JCCs are not seen as a threat to employers.

<<Table 4 about here»>

\section{Setting and Security of Tenure}

Showing that worker voice is more common in economies closest to the CME ideal is a first step. The next question is whether this makes a difference. What effect do unions have on key areas of work and employment relations? Or, is context more important than a union presence in determining the human resource management of firms? We explored the association between unionisation and the critical issue of security of tenure (Table 5).

<<Table 5 about here»> 
Panel A of Table 5 reports the proportion of firms for each category using different types of HRM policy and Panel B reports the tests for the differences in proportions. We examine job security. We look at the use of voluntary and compulsory redundancies as well as the use of outsourcing to reduce the workforce.

In line with our Hypotheses $2 a$ and $2 b$, there are significant differences between the four categories of firms in their usage of harder forms of numerical flexibility ${ }^{\text {iii }}{ }^{\text {iii] }}$. In detail, Panels $A$ and $B$ of Table 5 suggest that the use of voluntary redundancies is significantly lower in firms with neither works councils nor collective bargaining when compared to all other categories of firms. While there are no statistical differences in the use of voluntary redundancies among the other three categories, there is nevertheless an economic difference: $76 \%$ of firms with both collective bargaining and works councils use voluntary redundancies compared to only $71-72 \%$ for firms with either a works council or collective bargaining. From the opposite perspective, the percentage of firms using compulsory redundancies is significantly lower for the category of firms with both collective bargaining and works councils compared to all the other categories. Hence, there is evidence that if a decrease of the workforce is called for this is more likely to be done by softer policies (i.e. voluntary redundancies) rather than harder policies (i.e. compulsory redundancies) in firms with collective bargaining and works councils.

This is likely to reflect the fact that, in order to offset any union wage premium, firms may either already make use of very lean staffing and/or heavily invest in the skills and capabilities of such workers to enhance their effectiveness, making compulsory 
redundancies, in turn, less defensible. It could also reflect the effectiveness of collective organisation in protecting the interests of members (Gall, 2003b).

We also examine the use of outsourcing to reduce the workforce. The use of outsourcing is lowest in firms with neither collective bargaining nor non-union voice compared to firms with a works council and those with both a works council and collective bargaining and this difference is significant. However, there is no difference in the case of firms with only collective bargaining. Why is this? In many European countries, works councils are compulsory in firms above a certain size which, in turn, may be more likely to engage in outsourcing (simply because there are more opportunities for outsourcing). This does reveal that unions have not been very effective in braking outsourcing activities, particularly if outsourcing and an associated transfer of staff to the chosen provider are presented as the only alternative to immediate job losses. Conversely, it means that workers in nonunion firms are no more likely to have to contend with outsourcing.

\section{Effects of Sector and Firm Size}

We carried out several tests on size and sector differences (tables available from the authors). We found, using the European NACE categorisation, that there is evidence of differences between industries: some $e^{\mathrm{iv}[\mathrm{iv}]}$ had higher percentages of firms with no voice and some ${ }^{v[v]}$ had significantly higher percentages of firms with both collective bargaining and works councils, in line with the findings of Bechter et al. (2012). We also found that the relative size of the firm was related to whether or not firms recognized unions or had works councils; the larger the firm, the more likely this was the case. 


\section{Theoretical Implications}

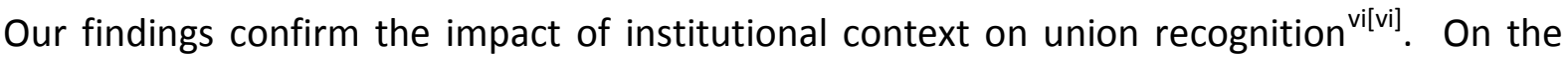
one hand, this corresponds with the broad categorizations of Hall and Soskice (2001). On the other hand, a closer scrutiny revealed that a single institutional feature on its own relative shareholder rights according to the anti-self-dealing index of Botero et al. (2004) had a direct impact. Does that mean the more complex social relationship orientated view of Hall and Soskice (2001) that encompasses many institutional features is essentially incorrect and that really only one institutional feature matters, and that there is little point in concerning oneself with other institutional features at all? There are two reasons why this is not the case. In looking at other dimensions of work and employment relations, for example, relative propensity to invest in people - using the same Cranet dataset - other research has found that a focus on shareholder rights alone provides a poor explanation (Goergen et al., 2012). In other words, what this study reveals is that in one specific area union recognition - a particular institutional feature has a strong pull. If shareholder rights are stronger, then, as suggested by a wide body of literature from very different starting points, it is likely that other stakeholders will lose out (Dore, 2000; Botero et al., 2004). However, this does not mean that in CMEs, shareholders may not do better in the long term through taking worker and other stakeholder rights (whether by choice or because they are compelled to by the law) more seriously even if, in the short term, their freedom of action is circumscribed (Dore, 2000). A fertile area for future research is to explore what other institutional features (for example, national education and training systems) may have a particularly strong impact on particular dimensions of work and employment practice at 
firm level. In other words, rather than taking a broadly composite approach to institutional effects (i.e. simply presenting a bundle of institutional features that exert a combined effect distinct from their individual impact) or focusing only on a single dimension (i.e. shareholder rights), a possible future research dimension might be to develop a comprehensive taxonomy of differing institutional dimensions, exploring which of the latter impacts on which firm practice.

Existing research, for example in some of the chapters in the 2001 Hall and Soskice volume and follow up volumes edited by Hancke, already highlights the specific impact of particular institutional domains, for example, training (Culpepper, 2001) and labour market regulation (Taylor, 2007: 244) on key dimensions of organisational practice. Amable (2003) provides a useful starting point in identifying a range of interlinked institutional features, which, however, each exert their own effects in particular areas; however, this study provides little in the way of firm level data, concentrating more on broad labour market and sectoral features according to context.

Again, whilst dichotomous approaches to categorizing capitalisms work quite well here, this is, once more, not true for other features of work and employment relations practice. Goergen et al. (2012) found that when it came to training and development, there were pronounced differences between Nordic social democratic capitalism and continental European coordinated markets, as suggested by Amable (2003). This would not only further highlight the extent to which some institutional dimensions exert a stronger impact on specific firm practices than others, but also that some broad features may be shared across CMEs (and, by implication, LMEs as well) and others not. In categorizing capitalisms, there is 
always a trade off between parsimony and nuance; what this study indicates is that dichotomous approaches have clear validity in some areas of work and employment practices, even if, as Whitley (1999) and Amable (2003) suggest, in others they do not.

We found that MMEs and EMEs, as predicted by Hancke et al. (2007), had characteristics somewhere between the LME and CME poles. However, MMEs were somewhat closer to the $\mathrm{CME}$ end of the spectrum when it came to unionisation and to some extent non union representative voice mechanisms. However, the survey excludes small enterprises; as Psychogios and Wood (2010) note, unions and collective representation continue to play a prominent role within larger organizations in MME states. In contrast, representation and collective rights are very much weaker in the very large SME sectors and the also important underground economies, areas not covered by the survey. Hence, it cannot be concluded that MME firms are generally closer to the CME model than those encountered in other types of capitalism, but larger ones are. However, it is likely that the differences between these archetypes will increase as radical austerity is enforced across the MME world. EMEs, meanwhile, were revealed to be a very diverse category from the LME like Estonia to countries such as Hungary and the Czech Republic, where levels of collective representation were higher. Indeed, it could be argued that the EME category is so disparate as to not constitute a meaningful archetype at all, reflecting the uneven and contested nature of change in the region.

Finally, and bound up with the above points, there are some features of work and employment practice - more specifically, relative propensity to make redundancies - that appear to be closely associated with another practice - union recognition, but less so with 
institutional setting. Why would this be the case, particularly as existing work suggests that the security of tenure represents a core distinction between different capitalist archetypes (Whitley, 1999; Hall and Soskice, 2001)? Gourevitch and Shinn (2007) argue that an important dimension of firm level governance is politics and shifts in political dynamics. Although it can be argued that the differences between established political parties have eroded in many national contexts, right wing parties maybe quite aggressive in promoting shareholder rights over those of other stakeholders, and left wing ones somewhat more cautious. Indeed, there is an extensive body of literature that argues that right wing parties are more associated with higher unemployment and job shedding (Palmer and Whitten, 2000; Alt, 1985). This would highlight the limitations of seeing institutions as somehow immutable, and the extent to which they may be constantly remoulded - on both incremental and radical lines - through the activities of social actors (Boyer, 2006; Lane and Wood, 2009). Although the challenging of existing norms may take place at a wide range of levels (Dore, 2008), the national political level is of particular importance (Gourevitch and Shinn, 2007). Again, a closer evaluation of the impact of ruling party ideology on firm level approaches to numerical flexibility would represent an important future research direction that, however, goes beyond the scope of this paper.

\section{Conclusions}

This paper provides clear empirical evidence that variety of capitalism makes a significant and persistent difference to the likelihood of finding firms that are unionised and that have formal representative voice mechanisms. Equally, firms from countries that have stronger shareholder as opposed to stakeholder rights are less likely to deal with trade unions and to have formal collective representation systems. It is common knowledge, of course, that 
there is a clear geographical difference in union representation, and this is bound up with different institutional traditions. However, we also found that the presence or absence of a union was bound up with the relative proclivity to make use of redundancies. This raises an important issue. On the one hand, national setting matters in determining whether or not a union is present. On the other hand, irrespective of setting, if a union is present, then it is likely to impact on such practices. In other words, it would be wrong to say that unions are somehow and necessarily less effective in some settings than others when it comes to protecting the interests of their members in terms of job security. This raises two important policy dimensions. Firstly, legislative interventions to improve collective rights are likely to have positive knock-on effects in promoting more worker friendly HRM policies. The converse is likely to be true when legislation weakens collective rights; this finding is of particular relevance given strong pressures on many national governments in Europe to promote the individualisation of industrial relations. Secondly, it seems that, even in more hostile settings, unions can and do make a difference.

We found predictable difference was in an area which would unambiguously reflect hard line HRM policies (c.f. Redman and Wilkinson 2009): non-union firms were more likely to make use of compulsory redundancies. Although there is little doubt that the relative power and impact of unions has diminished within many national settings, it is evident that this is one area where unions have retained a significant influence. Even if unions are relatively weak in organisational terms, they may still be able to hold management to account in this area, owing to accumulated experience and legal expertise, which may deter employers from rushing to make usage of redundancies, and encourage them to take the time to consider meaningful alternatives. As the pool of 'good' jobs continues to diminish in 
many national contexts, this vests unions with a continued importance even when collective mobilizational capabilities have eroded. 


\section{References}

Alt, J. (1985). Political Parties, World Demand and Unemployment. American Political Science Review, 79 (4): 1016-1040.

Amable, B. (2003). The Diversity of Modern Capitalism. Oxford: Oxford University Press.

Bechter, B., Brandl, B. and Meardi, G. (2012). Sectors or countries? European Journal of Industrial Relations, 18(3): 185-202.

Bosch, G., Rubery, J. and Lehndorff, S. (2007). European employment models under pressure to change. International Labour Review 146 (3-4): 253-277

Boni, G. (2009). Towards socially sensitive corporate restructuring? Comparative remarks on collective bargaining developments in Germany, France and Italy. International Labour Review 148 (1-2): 69-91

Botero, J., Djankov, S., La Porta, R. and Lopez-de-Silanes, F. (2004). The Regulation of Labor, The Quarterly Journal of Economics, November: 1339-1382.

Boyer, R. (2006). How do institutions cohere and change. In Wood, G. and James, P. (eds.), Institutions and Working Life, Oxford: Oxford University Press, pp.1-12.

Boyer, R. (2010). The Collapse of Finance, but Labour Remains Weak. Socio-Economic Review, 8, 2: 348-353.

Brewster, C., Wood, G., Croucher, R. and Brookes, M. (2007a). Collective and Individual Voice: Convergence in Europe? International Journal of Human Resource Management, 18 (7): 1246-1262.

Brewster, C., Wood, G., Croucher, R. and Brookes, M. (2007b) Are Works Councils and Joint Consultative Committees a Threat to Trade Unions? A Comparative Analysis. Economic and Industrial Democracy, 28: 49-77.

Brewster, C., Mayrhofer, W. and Morley, M. (eds.) (2004). Human Resource Management in Europe: Evidence of Convergence? London: Butterworth Heinemann.

Budd, J., Gollan, P. and Wilkinson, A. (2009). New Approaches to Employee Voice and Participation in Organisations, Human Relations, 63 (3): 1-8.

Culpepper, P. (2001). Employers, Public Policy and the Politics of Decentralized Cooperation in Germany and France. In Hall P and Soskice D (eds.), Varieties of Capitalism: The Institutional Basis of Competitive Advantage. Oxford: Oxford University Press, pp.275-306.

Deckop, J., Mangel, R. and Cirka, C. (1999). Getting More than You Pay for: isationOrganisational Citizenship Behavior and Pay-for-Performance Plans. The Academy of Management Journal, 42 (4): 420-428. 
Deeg, R. and Jackson, G. (2008). Comparing capitalisms: understanding institutional diversity and its implications for international business. Journal of International Business Studies, 39: 540-561

Doellgast, V., Holtgrewe, U. and Deery, S. (2009). The Effects of National Institutions and Collective Bargaining Arrangements on Job Quality in Front-Line Service Workplaces. Industrial and Labor Relations Review, 62 (4): 489-509.

Dore, R. (2000). Stock Market Capitalism: Welfare Capitalism. Cambridge: Cambridge University Press.

Dore, R. (2008). Best Practice Winning Out? Socio-Economic Review, 6 (4):779-784.

Dundon, T. (2002). Employer opposition and union avoidance in the UK. Industrial Relations Journal, 33 (3): 234 - 245.

Dundon, T. and Rollinson, T. (2004). Employment Relations in Non-Union Firms. London: Routledge.

Estevez-Abe, M., Iverson, T. and Soskice, D. (2001). Social Protection and the Formation of Skills: A Reinterpretation of the Welfare State. In Hall, P and Soskice, D (eds.), Varieties of Capitalism: The Institutional Basis of Competitive Advantage. Oxford: Oxford University Press, pp.145-183

Ferrer, A. and Lluis, S. (2009). Should Workers Care About Firm Size? Industrial and Labor Relations Review, 62 (1): 104-125.

Gall, G. (2003a). Introduction. In Gall, G (ed.), Union Organizing: Campaigning for Trade Union Recognition. London: Routledge, pp. 1-18.

Gall, G. (2003b). Employer Opposition to Union Recognition. In Gall, G (ed.), Union Organizing: Campaigning for Trade Union Recognition. London: Routledge, pp. 79-96.

Geman, R. (1996). Safeguarding Employee Rights in a Post-Union World: A New Conception of Employee Communities. Columbian Journal of Law and Social Problems, 369: 569-570.

Goergen, M., Brewster, C., Wood, G. and Wilkinson, A. (2012). Varieties of Capitalism and Investments in Human Capital, Industrial Relations, 51 (S1): 501-527.

Goergen, M., Brewster, C. and Wood, G. (2009). Corporate Governance Regimes and Employment Relations in Europe. Industrial Relations/Relations Industrielles, 64 (6): 620-640.

Gollan, P. (2000). Non-union forms of employee representation in the United Kingdom and Australia. In Kaufman B and Taras D (eds.), Non-union employee representation: history, contemporary practice, and policy. Armonk: M. E. Sharpe, pp. 410-452. 
Gollan, P. (2005). His masters voice - the interplay between non-union and union representation arrangements at Eurotunnel, In Baird M, Cooper, R and Westcott, M (eds.), Reworking work: AIRAANZ 05 : proceedings of the 19th conference of the Association of Industrial Relations Academics of Australia and New Zealand. Sydney: AIRAANZ, pp. 231238.

Gollan, P. (2006). A Process of Transition - Employer Strategies and Outcomes of Employee Voice at Eurotunnel. Socio-Economic Review, 4 (2): 337-351.

Gollan, P. (2009). Employer Strategies towards Non-Union Collective Voice. In Wilkinson A, Gollan, P, Marchington, $M$ and Lewin, D e (eds.), Oxford Handbook of Participation in Organisations. Oxford: Oxford University Press.

Gooderham, P.N., Nordhaug, O. and Ringdal, K. (2006). National Embeddedness and HRM Practices in US Subsidiaries in Europe and Australia. Human Relations 59 (11): 1491-1513.

Gourevitch, P. and Shinn, J. (2007). Political Power and Corporate Control: the New Global Politics of Corporate Governance. New Haven: Princeton University Press.

Guest D. (1987). Human resource management and industrial relations, Journal of Management Studies, 24: 503-21.

Hall, A.P. and Gingerich, D.W. (2004). Varieties of Capitalism and Institutional Complementarities in the Macroeconomy. An empirical Analysis. Max-Planck- Institut $f$. Gesellschaftsforschung - Discussion Paper 04/5. Cologne.

Hall, P. and Soskice, D. (2001). An Introduction to the Varieties of Capitalism. In Hall P and Soskice D (eds.), Varieties of Capitalism: The Institutional Basis of Competitive Advantage. Oxford: Oxford University Press, pp.1-70.

Hancke, B., Rhodes, M. and Thatcher, M. (2007). Introduction. In Hancke B, Rhodes M and Thatcher M (eds.), Beyond varieties of capitalism: conflict, contradiction, and complementarities in the European economy. Oxford: Oxford University Press.

Haynes, P., Boxall, P. and Macky, K. (2005). Non-Union Voice and the Effectiveness of Joint Consultation in New Zealand. Economic and Industrial Democracy, 26 (2): 229-256.

Hechter, M. (1987). Principles of Group Solidarity. Berkeley: University of California Press.

Hyman, R. (1975). Industrial Relations: A Marxist Introduction. London:Macmillan.

Hyman, R. (2002). European labour markets or European labour markets?: challenges for European labour. In Ottosson J and Magnusson L, (eds.), Europe: one labour market? London: Peter Lang. 
Kaufman, B. and Taras, D. (2000). Introduction In Kaufman B and Taras D, (eds.), Non-union employee representation: history, contemporary practice, and policy. Armonk: M. E. Sharpe, pp. 410-452.

Kaufman, B. (2004). What Unions Do: Insights from Economic Theory. Journal of Labor Research, 25 (3): 351-382.

Lane, C. and Wood, G. (2009). Diversity in Capitalism and Capitalist Diversity, Economy and Society, 38 (4): 531-551.

Marsden, D. (1999). A Theory of Employment Systems. Oxford: Oxford University Press.

Morin, M-L. (2005). Labour law and new forms of corporate organisation. International Labour Review 144 (1): 5-30

North, D.C. (1990). Institutions, Institutional Change and Economic Performance. Cambridge: Cambridge University Press.

Palmer, D. and Whitten, G. (2000). Government competence, economic performance and endogenous election dates. Electoral Studies, 19 (2-3): 413-426.

Pendleton, A., Poutsma, E., Brewster, C. and van Ommeren, .J (2002). Employee Share Ownership and Profit Sharing in the European Union: incidence, company characteristics and union representation. Transfer, 8 (1): 47-62.

Pendleton, A., Poutsma, E., Van Ommeren, J. and Brewster, C. (2003). The incidence and determinants of employee share ownership and profit sharing in Europe, In Kato, T. and Pliskin, J. (eds) The Determinants of the Incidence and Effects of Participatory Organisations. Advances in the Economic Analysis of Participatory and Labor Management, Volume 7, JAI Press, Greenwich, CT. 141-172

Poutsma, E. and de Nijs, W. (2003). Broad Based Employee Financial Participation in Europe, International Journal of Human Resource Management, 14 (6): 863-892.

Poutsma E, de Nijs W and Poole M (2003) The Global Phenomenon of Employee Financial Participation. International Journal of Human Resource Management, 14 (6): 855-862.

Psychogios, A. and Wood, G. (2010). Human Resource Management in Greece in Comparative Perspective: Alternative Institutionalist Perspectives and Empirical Realities. International Journal of Human Resource Management, 21 (14): 2614-2630.

Ramsay, H. (2003). Fool's Gold: European Works Councils and Workplace Democracy. Industrial Relations Journal, 28 (4): 314-322.

Redman, T. and Wilkinson, A. (2006). Downsizing. In Redman, T and Wilkinson, A (eds.), Contemporary Human Resource Management. London: FT/Prentice Hall.pp. 381-404. 
Rogers, J. and Streeck, W. (eds.) (1995). Works Councils: Consultation, Representation, and Cooperation in Industrial Relations. Chicago: University of Chicago Press.

Roe, M. (2003). The Political Determinants of Corporate Governance. Oxford: Oxford University Press.

Taras, D. (1999). Evolution of non-union employee representation in Canada. Journal of Labor Research, 20 (1): 53-72.

Taras, D. (2006). Non-union representation and employer intent. Socio-Economic Review, 4 (2): 321-336.

Taras, D. and Kaufman, B. (2006). Non-union employee representation in North America: Diversity, controversy, and uncertain future. Andrew Young School of Policy Studies Research Paper Series, No. 06-46. Atlanta: Georgia State University.

Taylor, M. (2007). Empirical Evidence against Technological Innovation, In Hancke B (ed.), Debating Varieties of Capitalism. Oxford: Oxford University Press, pp.221-247.

Terry, M. (1999). Systems of collective representation in non-union firms in the UK. Industrial Relations Journal, 30 (1): 16 - 30.

Whitley, R. (1999). Divergent Capitalisms. Oxford: Oxford University Press.

Wilkinson, A. (2005). Downsizing, rightsizing or dumbsizing? Quality, human resources and the management of sustainability. Total Quality Management and Business Excellence, 16 (8-9): 27-29. 
Table 1: Sample characteristics, union recognition and existence of works council and/or joint consultative committee

\begin{tabular}{|c|c|c|c|c|}
\hline Country & $\begin{array}{c}\text { Number of } \\
\text { firms }\end{array}$ & $\begin{array}{l}\text { Percentage of } \\
\text { sample }\end{array}$ & $\begin{array}{l}\text { Percentage of firms recognizing unions } \\
\text { for collective bargaining }\end{array}$ & $\begin{array}{l}\text { Percentage of firms with works council } \\
\text { and/or joint consultative committee }\end{array}$ \\
\hline Australia (LME) & 191 & $3.4 \%$ & $61 \%$ & $41 \%$ \\
\hline Austria (CME) & 198 & $3.6 \%$ & $100 \%$ & $90 \%$ \\
\hline Belgium (CME) & 201 & $3.6 \%$ & $88 \%$ & $90 \%$ \\
\hline Bulgaria (EME) & 101 & $1.8 \%$ & $55 \%$ & $39 \%$ \\
\hline Canada (LME) & 207 & $3.7 \%$ & $53 \%$ & $38 \%$ \\
\hline Cyprus (MME) & 39 & $0.7 \%$ & $79 \%$ & $31 \%$ \\
\hline Czech Republic (EME) & 62 & $1.1 \%$ & $94 \%$ & $15 \%$ \\
\hline Denmark (CME) & 288 & $5.2 \%$ & $77 \%$ & $71 \%$ \\
\hline Estonia (EME) & 73 & $1.3 \%$ & $26 \%$ & $22 \%$ \\
\hline Finland (CME) & 137 & $2.5 \%$ & $84 \%$ & $87 \%$ \\
\hline France (CME) & 130 & $2.3 \%$ & $99 \%$ & $99 \%$ \\
\hline Germany (CME) & 264 & $4.8 \%$ & $100 \%$ & $92 \%$ \\
\hline Greece (MME) & 148 & $2.7 \%$ & $77 \%$ & $39 \%$ \\
\hline Hungary (EME) & 60 & $1.1 \%$ & $87 \%$ & $68 \%$ \\
\hline Iceland (CME) & 56 & $1.0 \%$ & $86 \%$ & $29 \%$ \\
\hline Israel (MME) & 100 & $1.8 \%$ & $56 \%$ & $25 \%$ \\
\hline Italy (MME) & 80 & $1.4 \%$ & $86 \%$ & $60 \%$ \\
\hline Nepal (Other) & 96 & $1.7 \%$ & $72 \%$ & $19 \%$ \\
\hline Netherlands (CME) & 174 & $3.1 \%$ & $81 \%$ & $89 \%$ \\
\hline New Zealand (LME) & 183 & $3.3 \%$ & $62 \%$ & $27 \%$ \\
\hline Norway (CME) & 94 & $1.7 \%$ & $88 \%$ & $72 \%$ \\
\hline Philippines (Other) & 50 & $0.9 \%$ & $74 \%$ & $56 \%$ \\
\hline Slovakia (EME) & 212 & $3.8 \%$ & $48 \%$ & $40 \%$ \\
\hline Slovenia (CME) & 101 & $1.8 \%$ & $50 \%$ & $71 \%$ \\
\hline Spain (MME) & 139 & $2.5 \%$ & $73 \%$ & $91 \%$ \\
\hline Sweden (CME) & 238 & $4.3 \%$ & $100 \%$ & $89 \%$ \\
\hline Switzerland (CME) & 221 & $4.0 \%$ & $79 \%$ & $41 \%$ \\
\hline Tunisia (Other) & 146 & $2.6 \%$ & $100 \%$ & $95 \%$ \\
\hline Turkey (Other) & 157 & $2.8 \%$ & $48 \%$ & $13 \%$ \\
\hline Turkish Cypriot Community (Other) & 70 & $1.3 \%$ & $13 \%$ & $8 \%$ \\
\hline UK (LME) & 774 & $14.0 \%$ & $42 \%$ & $45 \%$ \\
\hline USA (LME) & 133 & $2.4 \%$ & $39 \%$ & $21 \%$ \\
\hline
\end{tabular}


Table 2: Importance of union recognition and non-union voice

\begin{tabular}{|ll|r|r|}
\hline \multirow{2}{*}{} & \multicolumn{2}{|c|}{$\begin{array}{c}\text { Do you recognise unions for } \\
\text { collective bargaining? }\end{array}$} \\
\cline { 2 - 4 } & \multicolumn{1}{|c|}{ No } & \multicolumn{1}{c|}{ Yes } \\
\hline $\begin{array}{l}\text { Do you have a joint } \\
\text { consultative committee or }\end{array}$ & Yes & $20.4 \%$ & $16.8 \%$ \\
works council? & $7.4 \%$ & $43.7 \%$ \\
\hline
\end{tabular}


Table 3: Capitalisms and non-union voice 
Panel A: Collective bargaining and works councils across varieties of capitalism 


\begin{tabular}{|l|r|r|r|r|r|}
\hline & \multicolumn{5}{|c|}{ Varietiesof capitalism } \\
\cline { 2 - 6 } & \multicolumn{1}{|c|}{ CME } & \multicolumn{1}{c|}{ LME } & \multicolumn{1}{c|}{ EME } & \multicolumn{1}{c|}{ MME } & \multicolumn{1}{c|}{ Other } \\
\hline $\begin{array}{l}\text { No collective bargaining and } \\
\text { no works council }\end{array}$ & $9.3 \%$ & $41.0 \%$ & $27.6 \%$ & $19.2 \%$ & $34.4 \%$ \\
$\begin{array}{l}\text { No collective bargaining, but } \\
\text { works council }\end{array}$ & $5.4 \%$ & $12.5 \%$ & $14.9 \%$ & $8.8 \%$ & $4.1 \%$ \\
$\begin{array}{l}\text { Collective bargaining, but no } \\
\text { works council }\end{array}$ & $14.9 \%$ & $19.4 \%$ & $27.6 \%$ & $26.7 \%$ & $22.7 \%$ \\
$\begin{array}{l}\text { Collective bargaining and works } \\
\text { council }\end{array}$ & $70.4 \%$ & $27.1 \%$ & $30.0 \%$ & $45.3 \%$ & $38.7 \%$ \\
\hline
\end{tabular}

Panel B: Comparison of percentages

\begin{tabular}{|c|c|c|c|c|c|}
\hline & \multicolumn{5}{|c|}{ VOC } \\
\hline & $\mathrm{CME}$ & LME & EME & MME & Other \\
\hline & (A) & (B) & (C) & (D) & (E) \\
\hline $\begin{array}{l}\text { No collective bargaining and } \\
\text { no works council }\end{array}$ & & $A C D$ & $A D$ & A & $A D$ \\
\hline $\begin{array}{l}\text { No collective bargaining, but } \\
\text { works council }\end{array}$ & & $A E$ & $A E$ & $A E$ & \\
\hline $\begin{array}{l}\text { Collective bargaining, but no } \\
\text { works council }\end{array}$ & & A & $A B$ & A B & A \\
\hline $\begin{array}{l}\text { Collective bargaining and } \\
\text { works council }\end{array}$ & $B C D E$ & & & B C & B \\
\hline
\end{tabular}


Table 4: Property rights and non-union voice

Panel A: Property rights index (mean)

\begin{tabular}{|l|r|r|r|r|}
\hline & $\begin{array}{c}\text { No collective } \\
\text { bargaining and no } \\
\text { works council }\end{array}$ & $\begin{array}{c}\text { No collective } \\
\text { bargaining, but } \\
\text { works council }\end{array}$ & $\begin{array}{c}\text { Collective } \\
\text { bargaining, but no } \\
\text { works council }\end{array}$ & $\begin{array}{c}\text { Collective } \\
\text { bargaining and } \\
\text { works council }\end{array}$ \\
\hline $\begin{array}{l}\text { La Porta et al. anti-self- } \\
\text { dealing index }\end{array}$ & 0.67 & 0.64 & 0.51 & 0.42 \\
\hline
\end{tabular}

Panel B: Comparison of means

\begin{tabular}{|l|l|l|l|c|}
\hline & $\begin{array}{c}\text { No collective } \\
\text { bargaining and no } \\
\text { works council }\end{array}$ & $\begin{array}{c}\text { No collective } \\
\text { bargaining, but } \\
\text { works council }\end{array}$ & $\begin{array}{c}\text { Collective } \\
\text { bargaining, but no } \\
\text { works council }\end{array}$ & $\begin{array}{c}\text { Collective } \\
\text { bargaining and } \\
\text { works council }\end{array}$ \\
\cline { 2 - 5 } & (A) & (B) & (C) & (D) \\
\hline $\begin{array}{l}\text { La Porta et al. anti-self- } \\
\text { dealing index }\end{array}$ & C D & C D & D & \\
\hline
\end{tabular}

Results are based on two-sided tests assuming equal variances with significancelevel 0.05 . For each significant pair, the key of the smaller category appears under the category with larger mean. Tests are adjusted for all pairwise comparisons using the Bonferroni correction. 


\section{Table 5: Union recognition, non-union voice and HRM practices}

Panel A: Proportions of firms

\begin{tabular}{|l|r|r|r|r|}
\hline & $\begin{array}{c}\text { No collective bargaining and } \\
\text { no works council }\end{array}$ & $\begin{array}{c}\text { No collective bargaining, } \\
\text { but works council }\end{array}$ & $\begin{array}{c}\text { Collective bargaining, but no } \\
\text { works council }\end{array}$ & $\begin{array}{c}\text { Collective bargaining and } \\
\text { works council }\end{array}$ \\
\hline Decrease by voluntary redundancies & 0.53 & 0.71 & .76 \\
Decrease by compulsory redundancies & 0.84 & 0.86 & 0.72 \\
Decrease by outsourcing & 0.33 & 0.55 & 0.85 \\
\hline
\end{tabular}

Panel B: Comparison of proportions

\begin{tabular}{|l|c|c|c|c|}
\hline \multirow{2}{*}{} & $\begin{array}{c}\text { No collective bargaining and } \\
\text { no works council }\end{array}$ & $\begin{array}{c}\text { No collective bargaining, } \\
\text { but works council }\end{array}$ & $\begin{array}{c}\text { Collective bargaining, but no } \\
\text { works council }\end{array}$ & $\begin{array}{c}\text { Collective bargaining and } \\
\text { works council }\end{array}$ \\
\cline { 2 - 6 } & (A) & (B) & (C) & (D) \\
\hline $\begin{array}{l}\text { Decrease by voluntary redundancies } \\
\text { Decrease by compulsory redundancies } \\
\text { Decreaseby outsourcing }\end{array}$ & D & A & A & D \\
\hline
\end{tabular}

Results are based on two-sided tests assuming equal variances with significance level 0.05 . For each significant pair, the key of the smaller category appears under the category with larger mean. Tests are adjusted for all pairwise comparisons using the Bonferroni correction. 


\section{Author's details}

Chris Brewster is Professor of International Human Resource Management at Henley Business School, University of Reading, UK, Nijmegen University, Netherlands, and Vaasa University, Finland. He researches international and comparative HRM and has published over twenty-five books and more than 175 articles. He has a doctorate from the LSE and an honorary doctorate from Vaasa University.

\section{Geoffrey Wood is Professor of International Business and Associate Dean at Warwick} Business School, University of Warwick. He currently is Honorary Professor of the University of the Witwatersrand, and Visiting Professor at Nelson Mandela University, both in South Africa, and Adjunct Professor at Griffith University, Australia. Geoffrey Wood has served as Commissioned Researcher for the South African Truth and Reconciliation Commission. He has authored/co-authored/edited twelve books, and over one hundred articles in peerreviewed journals.

Marc Goergen is Professor of Finance at Cardiff Business School, Cardiff University. He is also a Research Associate of the European Corporate Governance Institute (ECGI). Marc Goergen's research interests are in corporate governance and corporate finance. His research has been published in various journals, including the Journal of Finance.

\section{Endnotes}

\footnotetext{
${ }^{[i]}$ It should be noted that, whilst coming from a very different starting point, the analytical categories derived by Botero et al. in Europe broadly correspond with those of Amable (2003): common law (liberal market based), Scandinavian civil law (social democratic), German civil law (continental European capitalism), and French civil law (Mediterranean capitalism). A notable exception is the case of France.

[ii] The alternative Table 3 is available upon request from the authors.

[iii] These percentages are conditional percentages, i.e. they are based on the subsample of firms that have decreased their workforce. In detail, the relevant question in the Cranet questionnaire is as follows: "If the number of employees has decreased, have any of the following methods been used to reduce the number of people employed?"

[iv] These sectors include: Agriculture, hunting, forestry, fishing; Building and civil engineering; Retail and distribution, hotels, catering, repairs; Baking, finance, insurance, business services; Personal, domestic, recreational services; Other services; Education; Public administration; and Other.

${ }^{[v]}$ These sectors are: Energy and Water; Chemical products, extraction and processing of non-energy minerals; Metal manufacturing, mechanical, electrical and instrument engineering, office and data processing machinery; Transport and communication; and Health services.
} 
[vi] This was certainly the case when the data was collected. There is evidence that basic aspects of human resource management and industrial relations change only slowly (Mayrhofer, W., Brewster, C., Morley,M. and Ledolter, J. (2011) Hearing a Different drummer? Evidence of convergence in European HRM Human Resource Management Review 21 (1): 50-67) and it seems unlikely that many of the areas under consideration here (union recognition, works councils, etc) would be either affected by the economic crisis in the short term or operate differentially between the various categories we explore. 